Authors have nothing to disclose with regard to commercial support.

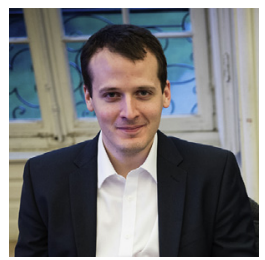

\section{PREVENTING PROSTHESIS-PATIENT MISMATCH: WITH THE CORRECT VALVE, WITH A CORRECT FORMULA, OR WITH BOTH?}

\section{To the Editor:}

We read with great interest the article of Sabik and colleagues ${ }^{1}$ reporting 1 -year outcomes with a novel stented bovine pericardial aortic bioprosthesis (PERIGON pivotal trial). It is striking that they report a 1-year prosthesispatient mismatch (PPM) rate of $75.5 \%$, with a severe PPM rate of $30.3 \%$. Considering the negative impact of PPM on postoperative left ventricular mass regression, functional improvement and quality of life, heart failure, and long-term survival after aortic valve replacement, ${ }^{2}$ this high rate of PPM may pose a problem for the widespread use of this novel bioprosthesis.

There may, however, be at least a partial explanation for the observed high PPM rate in the PERIGON population. Standard cutoffs for adjudicating PPM in a patient are an indexed effective orifice area of 0.85 to $0.65 \mathrm{~cm}^{2} / \mathrm{m}^{2}$ for $\mathrm{mod}$ erate PPM and less than $0.65 \mathrm{~cm}^{2} / \mathrm{m}^{2}$ for severe PPM. ${ }^{2}$ Recent studies have identified that PPM has less of an impact on survival in obese patients, ${ }^{3}$ most likely because of the smaller metabolic requirements of adipose tissue than other tissues. The Valve Academic Research Consortium has therefore recommended the use of a different, more liberal indexed effective orifice area cutoff of 0.70 to $0.60 \mathrm{~cm}^{2} / \mathrm{m}^{2}$ for moderate PPM and less than $0.60 \mathrm{~cm}^{2} /$ $\mathrm{m}^{2}$ for severe PPM in obese patients with a body mass index (BMI) of at least $30 \mathrm{~kg} / \mathrm{m}^{2}$, , which has even been lowered to an indexed effective orifice area of 0.70 to $0.56 \mathrm{~cm}^{2} / \mathrm{m}^{2}$ for moderate PPM and less than or equal to $0.55 \mathrm{~cm}^{2} / \mathrm{m}^{2}$ for severe PPM in the more recent guideline for the imaging assessment of prosthetic heart valves. ${ }^{4,5}$ These adjusted cutoffs for PPM are particularly relevant in contemporary

\footnotetext{
The Editor welcomes submissions for possible publication in the Letters to the Editor section that consist of commentary on an article published in the Journal or other relevant issues. Authors should: • Include no more than 500 words of text, three authors, and five references. • Type with double-spacing. • See http://jtcs.ctsnetjournals.org/ misc/ifora.shtml for detailed submission instructions. • Submit the letter electronically via jtcvs.editorialmanager.com. Letters commenting on an article published in the JTCVS will be considered if they are received within 6 weeks of the time the article was published. Authors of the article being commented on will be given an opportunity of offer a timely response ( 2 weeks) to the letter. Authors of letters will be notified that the letter has been received. Unpublished letters cannot be returned.
}

studies because of today's obesity epidemic. ${ }^{6}$ The average BMI of patients undergoing aortic valve replacement is increasing. ${ }^{7}$ The share of obese patients (BMI $\geq 30 \mathrm{~kg}$ / $\mathrm{m}^{2}$ ) was $44 \%$ in a recent clinical trial investigating another novel prosthetic heart valve. ${ }^{8}$ Although the BMI was not reported in the PERIGON study, the mean body surface are of $2.0 \pm 0.2 \mathrm{~m}^{2}$ seems to be somewhat higher than expected in a nonobese adult population, suggesting that the study included many obese patients. ${ }^{9}$ Nevertheless, the adjusted cutoffs for defining PPM in obese patients were not applied in the PERIGON study, and the rate of PPM is therefore overestimated. We urge Sabik and colleagues ${ }^{1}$ to adjust the criteria for PPM in obese patients in future analyses of PPM.

Andras P. Durko, $M D$ Mevlüt Çelik, BSc

Stuart J. Head, MD, PhD

Department of Cardiothoracic Surgery Erasmus University Medical Center Rotterdam, The Netherlands

\section{References}

1. Sabik JF III, Rao V, Lange R, Kappetein AP, Dagenais F, Labrousse L, et al. Oneyear outcomes associated with a novel stented bovine pericardial aortic bioprosthesis. J Thorac Cardiovasc Surg. 2018;156:1368-77.e5.

2. Head SJ, Mokhles MM, Osnabrugge RL, Pibarot P, Mack MJ, Takkenberg JJ, et al The impact of prosthesis-patient mismatch on long-term survival after aortic valve replacement: a systematic review and meta-analysis of 34 observational studies comprising 27186 patients with 133141 patient-years. Eur Heart J. 2012;33: 1518-29.

3. Coisne A, Ninni S, Edmé JL, Modine T, Mouton S, Pilato R, et al. Obesity paradox in the clinical significance of effective prosthetic orifice area after aortic valve replacement. JACC Cardiovasc Imaging. 2019;12:208-10.

4. Kappetein AP, Head SJ, Généreux P, Piazza N, van Mieghem NM, Blackstone EH et al. Valve Academic Research Consortium-2. Updated standardized endpoint definitions for transcatheter aortic valve implantation: the Valve Academic Research Consortium-2 consensus document. J Thorac Cardiovasc Surg. 2013; $145: 6-23$.

5. Lancellotti P, Pibarot P, Chambers J, Edvardsen T, Delgado V, Dulgheru R, et al Recommendations for the imaging assessment of prosthetic heart valves: a report from the European Association of Cardiovascular Imaging endorsed by the Chinese Society of Echocardiography, the Inter-American Society of Echocardiography, and the Brazilian Department of Cardiovascular Imaging. Eur Heart $J$ Cardiovasc Imaging. 2016;17:589-90.

6. Ng M, Fleming T, Robinson M, Thomson B, Graetz N, Margono C, et al. Global, regional, and national prevalence of overweight and obesity in children and adults during 1980-2013: a systematic analysis for the Global Burden of Disease Study 2013. Lancet. 2014;384:766-81.

7. Dunning J, Gao H, Chambers J, Moat N, Murphy G, Pagano D, et al. Aortic valve surgery: marked increases in volume and significant decreases in mechanical valve use-an analysis of 41,227 patients over 5 years from the Society for Cardiothoracic Surgery in Great Britain and Ireland National database. J Thorac Cardiovasc Surg. 2011;142:776-82.e3.

8. Puskas JD, Bavaria JE, Svensson LG, Blackstone EH, Griffith B, Gammie JS, et al; COMMENCE Trial Investigators. The COMMENCE trial: 2-year outcomes with an aortic bioprosthesis with RESILIA tissue. Eur J Cardiothorac Surg. 2017;52: 432-9.

9. Verbraecken J, Van de Heyning P, De Backer W, Van Gaal L. Body surface area in normal-weight, overweight, and obese adults. A comparison study. Metabolism. 2006;55:515-24.

https://doi.org/10.1016/j.jtcvs.2018.09.006 